\title{
Assessment of Serotonin Metabolite 5-hydroxyindoleacetic Acid Levels in Urine Sample for Diagnosis and Treatment Efficacy in Children with Dysfunctional Voiding and Their Interaction with Biofeedback Therapy
}

\author{
Disfonksiyonel İşemeli Çocukların Tanısında ve Tedavi Etkinliğinin Değerlendirilmesinde \\ Serotonin Metaboliti Idrar 5-hidroksiindolasetik Asit Düzeyleri ve Biofeedback Tedavisi ile \\ Etkileşimi
}

\author{
(1) Bahadır Topuz1', (1) Giray Ergin22, (1) Burak Köprü2, (1) Turgay Ebiloğlu1', (1) Hasan Cem Irkılata33, (1) Yusuf Kibar2, \\ (D) Musa Murat Dayanç²
}

1 University of Health Sciences, Gülhane Training and Research Hospital, Clinic of Urology, Ankara, Turkiye

2Koru Hospital, Clinic of Urology, Ankara, Turkiye

${ }^{3}$ Davraz Yaşam Hospital, Clinic of Urology, Isparta, Turkiye

\begin{abstract}
What's known on the subject? and What does the study add?
Dysfunctional voiding is one of the childhood urological problems that constitute a serious problem for families and children. We still do not know if a problem at the level of neurotransmitter metabolite in the central nervous system plays a role in the etiology of dysfunctional voiding. New studies are needed to get more information about the role of neuromodulators in the etiology and treatment of dysfunctional voiding. Therefore, this study will be beneficial for researchers in shaping the relationship between dysfunctional voiding and neuromodulators.
\end{abstract}

\begin{abstract}
Objective: Dysfunctional voiding (DV), which is explained as an incoordination between the external urethral sphincter and the bladder, is a situation developing in neurologically normal children. Serotonin has some effects on the lower urinary tract which cannot be fully explained. The selective 5-hydroxyindoleacetic acid (5-HIAA) agonist improves voiding efficacy in the rat model with voiding dysfunction as serotonin. Serotonin decomposes to 5-HIAA which excreted from urine. We considered that a problem in neuromodulator levels can lead to DV and evaluated the levels of 5-HIAA in urine.

Materials and Methods: Our study included 130 children aged 5-15 years who were diagnosed with DV and 48 children with no urological complaints as controls. Urine samples were taken only once in control group, and 3 times [before and after the biofeedback treatment (sixth month and twelfth month)] in the study group to determine the difference and the interaction between 5-HIAA and biofeedback therapy.

Results: Biofeedback therapy was found to be an effective method in the treatment of DV. However, there was no significant difference in the level of mean urine $5-\mathrm{HIAA} /$ creatinine (u5-HIAA/Cr) between study $(6.139 \pm 3.652)$ and control groups $(6.374 \pm 4.329)(p=0.751)$. The mean u5-HIAA/ $\mathrm{Cr}$ levels in the DV group at baseline and at the end of biofeedback therapy ( $6^{\text {th }}$ month) were $6.249 \pm 4.132$ and $6.19 \pm 4.715$, respectively ( $p=0.951$ ). The mean u5-HIAA/Cr levels in the DV group at baseline and at 12 months were $5.901 \pm 3.291$ and $6.644 \pm 4.206$, respectively ( $p=0.557$ ). There was no significant difference in $\mathrm{u} 5$-HIAA/Cr levels between pre-treatment and post-treatment in the DV group.

Conclusion: We still do not know if a problem at the level of neurotransmitter metabolite in the central nervous system plays a role in the etiology of DV. We evaluated this relationship, but we could not find a significant result. New studies are needed to get more information about the role of neuromodulators in the etiology and treatment of DV.
\end{abstract}

Keywords: Biofeedback therapy, Dysfunctional voiding, 5-hydroxyindoleacetic acid, Serotonin

Correspondence: Bahadır Topuz MD, University of Health Sciences, Gülhane Training and Research Hospital, Clinic of Urology, Ankara, Turkiye Phone: +90 3123045607 E-mail: drbtopuz@gmail.com ORCID-ID: orcid.org/0000-0001-6209-803X

Received: 10.01.2018 Accepted: 25.06.2018

Cite this article as: Topuz B, Ergin G, Köprü B, Ebiloğlu T, Irkılata HC, Kibar Y, Dayanç MM. Assessment of Serotonin Metabolite 5-hydroxyindoleacetic Acid Levels in Urine Sample for Diagnosis and Treatment Efficacy in Children with Dysfunctional Voiding and Their Interaction with Biofeedback Therapy. J Urol Surg 2018;5(4):176-181.

๑Copyright 2018 by the Association of Urological Surgery / Journal of Urological Surgery published by Galenos Publishing House. 


\section{Öz}

Amaç: Disfonksiyonel işeme(Di), nörolojik olarak normal çocuklarda gelişen bir durumdur ve dışüretral sfinkter ile mesane arasındaki koordinasyonsuzluk olarak açıklanmaktadır. Serotoninin alt üriner sistem üzerinde tam olarak açıklanamayan bazı etkileri vardır. Selektif 5-hidroksiindolasetik asit (5HIAA) agonisti, serotonin gibi işeme disfonksiyonu olan sıçan modelinde işeme etkinliğini geliştirir. Serotonin 5-HIAA'ya parçalanarak idrar ile atılır. Nöromodülatör düzeylerindeki bir sorunun Di etiyolojisine yol açabileceğini düşünüyorduk ve idrardaki 5-HIAA düzeylerini değerlendirdik.

Gereç ve Yöntem: Çalışmamız Dí tanısı konulan 5-15 yaş arasındaki 130 çocuk ile 2013 ve 2015 yılları arasında planlandı. İdrar numuneleri, kontrol grubunda sadece bir kez ve çalışma grubunda biofeedback tedavisi ile olan farkı ve etkileşimi belirlemek için 3 kez [biofeedback tedavisinden önce ve sonra (altıncı ay ve on ikinci ay)] alındı.

Bulgular: Biofeedback tedavisinin Díde etkili bir yöntem olduğu bulundu. Ancak çalışma $(6,139 \pm 3,652)$ ve kontrol grubu $(6,374 \pm 4,329)$ arasında ortalama idrar 5-HIAA/kreatinin ( $\mathrm{u} 5-\mathrm{HIAA} / \mathrm{Cr}$ ) düzeyinde anlamlı farklılık yoktu $(\mathrm{p}=0,751)$. Di grubunda, biofeedback tedavisinin başlangıcında ve sonundaki (6. ay) ortalama u5-HIAA/Cr düzeyleri sırasıyla $6,249 \pm 4,132$ ve $6,19 \pm 4,715$ idi $(p=0,951)$. Di grubunda, biofeedback tedavisinin başlangıcında ve on ikinci ayda ortalama u5-HIAA/Cr düzeyleri sırasıyla $5,901 \pm 3,291$ ve $6,644 \pm 4,206$ idi ( $p=0,557)$. Di grubunda tedavi öncesi ve sonrası u5-HIAA/Cr düzeyleri arasında anlamlı fark yoktu.

Sonuç: Di etiyolojisinde merkezi sinir sisteminde nörotransmitter metaboliti seviyesinde bir sorun olup olmadığını hala bilmiyoruz. Bu ilişkiyi değerlendirdik, ancak önemli bir sonuç bulamadık. Di etiyolojisi ve tedavisinde nöromodülatörlerin rolü hakkında daha fazla bilgi edinmek için yeni çalışmalara ihtiyaç vardır.

Anahtar Kelimeler: Biofeedback tedavisi, Disfonksiyonel işeme, 5-hidroksiindolasetik asit, Serotonin

\section{Introduction}

Dysfunctional voiding (DV) is a situation that occurs in neurologically normal children during toilet training period and explained as an incoordination between the external urethral sphincter and the bladder (1). Actually, it occurs as a result of wrong voiding habits (2).

In the standardization article published by International Children's Continence Society in 2016, various sub-types regarding the storage and voiding phase of lower urinary tract dysfunction (LUTD) are determined (1). Accordingly, overactive bladder, underactive bladder, DV and bladder neck dysfunction included in the sub-types of LUTD. In addition, LUTD is present in more rare subtypes such as voiding postponement, vaginal reflux, Hinman syndrome, bladder outlet obstruction, and giggle incontinence. DV is a voiding phase disease. DV symptoms may include hesitancy, straining, intermittency, dysuria, holding maneuvers, increased voiding frequency, incontinence, urgency, nocturia, and constipation (1). There is a pelvic floor activity in DV, which is manifested by a staccato and/or interrupted pattern in uroflowmetry with simultaneous electromyography (UF-EMG) (3). DV can lead to recurrent urinary tract infection, vesicoureteral reflux and chronic renal failure in children (4). DV can be evaluated with detailed history, physical examination, 3-day-bladder diary, urinary ultrasonography, the DV and Incontinence Symptoms Score (DVISS), UF-EMG, and post-void residual urine (PVR) measurement without a need for invasive examinations (5).

In the central nervous system (CNS), serotonin and other neuromodulators have some effects on lower urinary tract storage and emptying, however, they could not be fully demonstrated till now $(6,7)$. Serotonergic neurons in the CNS are located mainly in the raphe nuclei in the brain stem. Serotonin, which is synthesized in serotonergic nerve endings, is stored together with other substrates in vesicles (8). Serotonin decomposes to 5-hydroxyindoleacetic acid (5-HIAA) by monoamine oxidase which is excreted via urine (9). Serotonergic neural transport is regulated by serotonin receptors (5-HT). Studies on voiding function are related to the $5 \mathrm{HT}_{1 \mathrm{~A}}$ receptor. It has been shown that $5-\mathrm{HT}_{1 \mathrm{~A}}$ receptor agonist 8-hydroxy-2-(di-n-propylamino) tetralin (8-OH-DPAT) injected in anesthetized rats with DV model activated the voiding reflex, increased the frequency of bladder contractions, increased the voiding volume, reduced bladder capacity, reduced intravesical pressure, and decreased PVR (10). The 5- $\mathrm{HT}_{1 \mathrm{~A}}$ agonist 8-OH-DPAT administered to rats with spinal cord injury increased the external urethral sphincter relaxation period (11). Serotonin and 5-HIAA levels may be important in children with DV.

In this study, we consider that a problem in neuromodulator levels in CNS can lead to DV. We aimed to examine the the value of serotonin metabolite 5-HIAA levels in urine sample for diagnosis and assessment of treatment efficacy in children with DV and their interaction with biofeedback therapy.

\section{Materials and Methods}

This study was approved by the Gülhane Military Medical Academy Ethics Committee (approval number: 15, date: 3 April 2013) and followed the Institution's Review Board of Human Subject Guidelines. Consent form was filled out by all participants. Our study was designed as prospective, double blind and controlled study including 130 children aged 5-15 years who attended our urology department from April 2013 to April 2015. A thorough physical examination including the urogenital system and neurological system was conducted. 
All patients were evaluated by urinalysis, urine culture, serum urea and creatinine, lumbosacral spine radiography, and urinary ultrasonography.

Thirteen patients, who were diagnosed with urolithiasis, persistent recurrent urinary tract infections and syringomyelia, were excluded from the study. Families of 117 children who participated in the study filled the DVISS questionnaire and 3-day-voiding diary. Forty-eight children had no urological complaints and the DVISS was below 9. In fact, these children consisted of those who attended the pediatric outpatient clinic for height and weight measurements and were directed to our study. DV was not considered in these children and were selected as the control group. Sixty-nine children with a DVISS of 9 or greater, who had a staccato voiding pattern and presence of EMG activity in UF-EMG test and a PVR greater than $20 \mathrm{cc}$, were evaluated as having DV. UF-EMG (MMS USA, Inc., 383 Central Ave., Suite LL40 Dover, NH 03820, USA) and PVR measurements were conducted for at least twice to confirm the diagnosis of DV in 69 children. UF-EMG was conducted by an experienced technician. PVR was measured with a BladderScan BVI 6100 (Diagnostic Ultrasound, Bothell, WA, USA). DV was evaluated in children without the necessity to use invasive urodynamic studies.

Any situation that would cause a decrease or increase in serotonin and 5-HIAA, such as carcinoid tumor, celiac disease, Whipple disease, cystic fibrosis, bronchial carcinomas, depression, ileum resection, phenylketonuria, Hartnup's disease, and migraine, was included in the exclusion criteria. No detailed diagnostic tests was done for diseases that cause an increase or decrease in serotonin and urine 5-HIAA. To exclude these diseases, the medical history of the family was questioned and a detailed physical examination was performed. Children with spinal cord injury or neurogenic bladder were also excluded from the study.

Children, who were admitted to our outpatient clinic with DV, were taken to biofeedback treatment. The biofeedback treatment protocol, which is well established in our clinical practice, was to take place once a week for the first month. The biofeedback treatment was scheduled for at least six sessions.

The success of biofeedback therapy was evaluated with questioning the patient's symptoms (subjective evaluation criteria) and recovery DVISS, UF-EMG, and PVR (objective evaluation criteria). Urine samples for 5-HIAA levels were taken only once in control group, and 3 times [before and after the biofeedback treatment $\left(6^{\text {th }}\right.$ month and $12^{\text {th }}$ month)] in the study group to determine the difference and interaction with biofeedback therapy.

Success was defined as an improvement of more than 90\% in patients' symptoms.
A 24-hour urine sample is preferred for the measurement of serotonin metabolite and degradation product 5-HIAA in urine. If it is not possible to collect a 24-hour urine sample, a spot urine sample may be used as well as a urine creatinine level. Urine 5-HIAA levels can be normalized by dividing urine creatinine concentrations and the result can be determined as " $\mathrm{mg} / \mathrm{g}$ creatinine". When urine is collected according to the 24-hour urine procedure, the normal value range for urinary 5-HIAA is 2-8 $\mathrm{mg}$ in adults (12). There is no clear data on this value for children. When we examined studies evaluating urinary 5-HIAA levels in children, we saw that they were planned with a spot urine sample (13). We preferred spot urine sample in our study because of the difficulty in collecting and storing 24hour urine sample in children, parental non-compliance, risk of contamination with defecation, and it was quickly affected by the storage conditions during the molecular collection procedure. However, the spot urine 5-HIAA level $(\mathrm{mg} / \mathrm{L})$ was normalized to urine creatinine $(\mathrm{mg} / \mathrm{dL})$ and the result was reported as "mg/g creatinine" in order to achieve more accurate results and more valuable study.

Three milliliter urine samples were collected in the morning as the first urine and stored in the refrigerator at $-80{ }^{\circ} \mathrm{C}$ until the end of the study. Only one urine sample was collected from the children in the control group and kept as in the patient group.

Urine 5-HIAA measurements were made by the highperformance liquid chromatography method (Shimadzu, Japan) in spot urine samples. Measurements were made using an Eureka (Italy) kit in this system. Analyzes were completed with a $50 \mu \mathrm{L}$ sample injection and a $1.2 \mathrm{~mL} / \mathrm{min}$ mobile phase flow.

\section{Statistical Analysis}

Statistical analysis was done using the Statistical Package for Social Sciences 15.0 software (SPSS 15.0 for Windows, Chicago, IL, USA). Descriptive statistics were noted with numbers: mean \pm standard deviation with minimum-maximum. A t-test was used to compare the groups. Categorical variables, expressed as percentages, were analyzed using the McNemar test. We also performed comparisons using the Wilcoxon test for subgroup analysis. A $p$ value of less than 0.05 was considerd statistically significant.

\section{Results}

Our study was conducted with a total of 117 children, 69 in the patient group and 48 in the control group. The mean age of the patients was $8.65 \pm 2.53$ (range: $5-15$ ) years and $16(23 \%)$ of them were boys and $53(77 \%)$ were girls. The mean age of the control group was $9.20 \pm 2.86$ (range 5-15) years and 26 (54\%) of them were boys and $22(46 \%)$ were girls. The results of DVISS for the patient group and the control group are depicted in Figure 1. 
The objective parameters such as voiding pattern, UF-EMG and PVR were improved with the success rates of $84 \%(p<0.001)$, $63 \%(p<0.001)$ and $72 \%(p<0.001)$, respectively. We found that in DVISS parameters such as daytime incontinence, enuresis, frequency, straining, dysuria, intermittency, incomplete emptying, urgency, making holding maneuvers, urgency incontinence, and constipation were improved with success rates of $63 \%, 41 \%, 56 \%, 90 \%, 73 \%, 68 \%, 62 \%, 42 \%, 58 \%$, $81 \%$ and $62 \%$, respectively (Table 1 ). The mean DVISS in 62 patients before and after biofeedback treatment was found to be $13.08 \pm 7.34$ and $5.62 \pm 5.51(p<0.001)$. Twenty-six $(50 \%)$ of 52

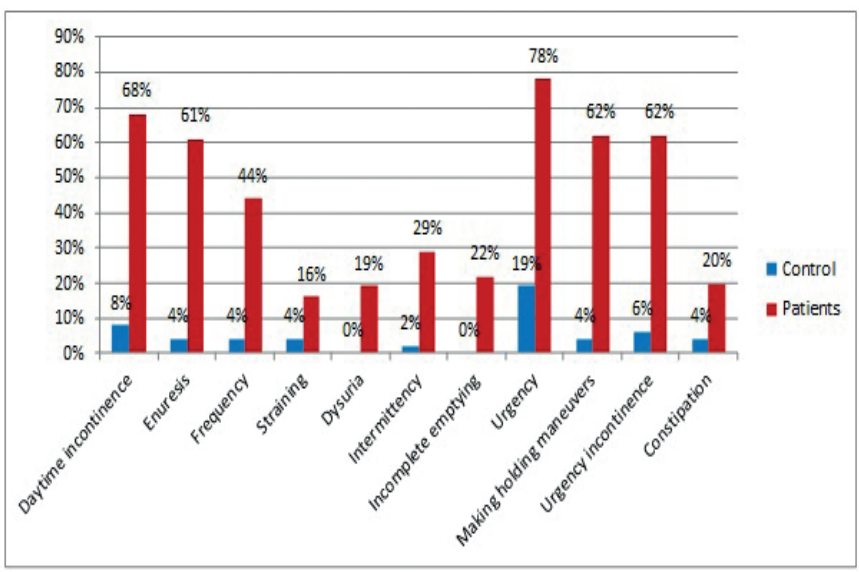

Figure 1. The answered Dysfunctional Voiding and Incontinence Symptoms Score questions for patient and control group

\begin{tabular}{|c|c|c|c|c|}
\hline DVISS questions & $\begin{array}{l}\text { Before } \\
\text { biofeedback } \\
\text { therapy }\end{array}$ & $\begin{array}{l}\text { After } \\
\text { biofeedback } \\
\text { therapy } \\
\left(6^{\text {th }} \text { month }\right)\end{array}$ & $\begin{array}{l}\text { Success } \\
(\%)\end{array}$ & $\mathbf{p}^{*}$ \\
\hline $\begin{array}{l}\text { Daytime } \\
\text { incontinence }\end{array}$ & 41 & 15 & 63 & $<0.001$ \\
\hline Enuresis & 37 & 22 & 41 & 0.001 \\
\hline Frequency & 25 & 11 & 56 & 0.013 \\
\hline Straining & 10 & 1 & 90 & 0.021 \\
\hline Dysuria & 11 & 3 & 73 & 0.039 \\
\hline Intermittency & 19 & 6 & 68 & 0.021 \\
\hline $\begin{array}{l}\text { Incomplete } \\
\text { emptying }\end{array}$ & 13 & 5 & 62 & 0.109 \\
\hline Urgency & 48 & 28 & 42 & $<0.001$ \\
\hline $\begin{array}{l}\text { Making holding } \\
\text { maneuvers }\end{array}$ & 36 & 15 & 58 & $<0.001$ \\
\hline $\begin{array}{l}\text { Urgency } \\
\text { incontinence }\end{array}$ & 37 & 7 & 81 & $<0.001$ \\
\hline Constipation & 13 & 5 & 62 & 0.039 \\
\hline
\end{tabular}

patients whose quality of life was affected before biofeedback treatment had a complete improvement in quality of life $(p<0.001)$.

There was no significant difference in the level of mean urine 5 -HIAA/creatinine (u5-HIAA/Cr) between the DV $(6.139 \pm 3.652)$ and the control groups $(6.374 \pm 4.329)(p=0.751)$ (Table 2).

The $45-\mathrm{HIAA} / \mathrm{Cr}$ values in patients in DV and control groups were evaluated in terms of gender. In DV group, the mean u5-HIAA/ $\mathrm{Cr}$ levels in male and female patients were $7.353 \pm 3.044$ (3.561$16.247)$ and $5.772 \pm 3.765(0.84-25.011)$, respectively ( $p=0.039)$. When the pre-treatment $\mathrm{u} 5-\mathrm{HIAA} / \mathrm{Cr}$ values were compared in DV group, pre-treatment $\mathrm{u} 5-\mathrm{HIAA} / \mathrm{Cr}$ values in females were significantly lower than in males. In control group, the mean u5-HIAA/Cr levels in male and female patients were $6.57 \pm 4.752$ $(0.431-25.079)$ and $6.143 \pm 3.866(2.235-19.174)$, respectively $(p=0.725)$. There was no significant difference between genders in control group.

Table 2. Comparison of urine 5-hydroxyindoleacetic acid/ creatinine levels between dysfunctional voiding and control groups

\begin{tabular}{llllll}
\hline & & $\mathbf{n}^{\mathbf{a}}$ & Mean $^{\mathbf{b}}$ & SD & $\mathbf{p}^{\mathbf{c}}$ \\
\hline \multirow{2}{*}{ u5-HIAA/Cr } & DV & 69 & 6.139 & 3.652 & \multirow{2}{*}{0.751} \\
& Control & 48 & 6.374 & 4.329 & \\
\hline
\end{tabular}

DV: Dysfunctional voiding, u5-HIAA/Cr: Urine 5-hydroxyindoleacetic acid/creatinine, SD: Standard deviation

a: The number of children in dysfunctional voiding and control groups

b: Urine 5-hydroxyindoleacetic acid/creatinine ( $\mathrm{mg} / \mathrm{g}$ creatinine) c: $t$ test

Table 3. Comparison of pre-treatment urine 5-hydroxyindoleacetic acid/creatinine levels and those at the end of biofeedback therapy $\left(6^{\text {th }}\right.$ month in completed the study)

\begin{tabular}{llllll}
\hline & $\mathbf{n}^{\text {a }}$ & Mean $^{\mathbf{b}}$ & SD & $\mathbf{p}^{\mathbf{c}}$ \\
\hline u5-HIAA/Cr & 45 & 6.249 & 4.132 & $\begin{array}{l}\text { At the end of } \\
\text { biofeedback } \\
\text { therapy (6 }\end{array}$ \\
th month)
\end{tabular}

u5-HIAA/Cr: Urinary 5-hydroxyindole acetic acid, SD: Standard deviation

a: The number of patients who completed the study

b: Urine 5-hydroxyindoleacetic acid/creatinine ( $\mathrm{mg} / \mathrm{g}$ creatinine) c: Wilcoxon test

Table 4. Comparison of pre-treatment urine 5-hydroxyindoleacetic acid/creatinine levels and the levels at the $12^{\text {th }}$ month $\left(12^{\text {th }}\right.$ month in completed the study)

\begin{tabular}{llllll}
\hline & & $\mathbf{n}^{\mathbf{a}}$ & Mean $^{\mathbf{b}}$ & SD & $\mathbf{p}^{\mathbf{c}}$ \\
\hline \multirow{2}{*}{ u5-HIAA/Cr } & Baseline & 24 & 5.901 & 3.291 & \multirow{2}{*}{0.557} \\
& $12^{\text {th }}$ months & 24 & 6.644 & 4.206 & \\
\hline
\end{tabular}

u5-HIAA/Cr: Urinary 5-hydroxyindole acetic acid, SD: Standard deviation a: The number of patients who completed the study

b: Urine 5-hydroxyindoleacetic acid/creatinine ( $\mathrm{mg} / \mathrm{g}$ creatinine)

c: Wilcoxon test 
There were 69 patients at the beginning for $u 5-\mathrm{HIAA} / \mathrm{Cr}$ levels, which declined to 45 and 24 patients at the $6^{\text {th }}$ and $12^{\text {th }}$ months, respectively. The mean $\mathrm{u} 5-\mathrm{HIAA} / \mathrm{Cr}$ levels in DV group at baseline and at the end of biofeedback therapy ( $6^{\text {th }}$ month) were 6.249 \pm 4.132 and $6.19 \pm 4.715$, respectively $(p=0.951)$ (Table 3). The mean u5-HIAA/Cr levels in DV group at baseline and at 12 months were $5.901 \pm 3.291$ and $6.644 \pm 4.206$, respectively $(\mathrm{p}=0.557)$ (Table 4). There was no significant difference in u5$\mathrm{HIAA} / \mathrm{Cr}$ levels between pre-treatment and post-treatment in DV group.

\section{Discussion}

DV is one of the childhood urological problems that constitute a serious problem for families and children. Any neurogenic or non-neurogenic disease that increases intrabladder pressure adversely affects the upper urinary tract (4). DV is a nonneurogenic lower urinary tract disease which can lead to recurrent urinary tract infection, vesicoureteral reflux and chronic renal failure in children (14).

In the CNS, transmitters and modulators have various effects on contraction and relaxation in the lower urinary system (15). When the literature is examined, it appears that there are a number of studies investigating the relationship between 5 -HT and voiding functions in animals $(10,11,15,16)$. Studies on voiding function are related to the $5 \mathrm{HT}_{1 \mathrm{~A}}$ receptor. It has been shown that when injected in anesthetized rats with DV model, the $5-\mathrm{HT}_{1 \mathrm{~A}}$ receptor agonist 8-OH-DPAT activated the voiding reflex, increased the frequency of bladder contractions, increased the voiding volume, reduced the bladder capacity, reduced intravesical pressure and decreased PVR (10). It has been demonstrated that the selective $5-\mathrm{HT}_{1 \mathrm{~A}}$ agonist improved voiding efficacy in the rat model with voiding dysfunction. Serotonin which excreted with urine decomposes to 5-HIAA.

In the DV etiology, there is an inadequacy of complete relaxation of the pelvic floor muscles or urinary sphincter during voiding (17). We still do not know if there is a problem at the level of neurotransmitter or neurotransmitters metabolite in the CNS. There is no study in humans that evaluates this etiology.

We evaluated this relationship, but we could not find a significant result. We did not find significant differences in u5-HIAA/Cr levels between DV and control groups. There was no significant difference in $\mathrm{u} 5-\mathrm{HIAA} / \mathrm{Cr}$ levels between pretreatment and post-treatment in DV group.

Biofeedback therapy is a simple, effective, well tolerated and non-invasive treatment method for children with DV (18). Krzemiñska et al. (19) reported biofeedback therapy outcomes in children with DV.After 2 months of biofeedback therapy, children had a 50.7\% improvement in daytime incontinence and 53.65\% improvement in enuresis. Kibar et al. (20) reported results of biofeedback treatment in children aged 5-14 years with DV and vesicoureteral reflux. They reported significant, improvements in enuresis, daytime wetting, constipation, frequency and urgency $(82 \%, 70 \%, 78 \%, 76 \%$ and $71 \%$, respectively) in older children who received biofeedback therapy.

Shei Dei Yang et al. (21) reported outcomes of a short course biofeedback treatment in children with DV. They showed a 90\% improvement in UF-EMG pattern. In addition, PVR decreased from 54.5 to $21.3 \mathrm{~mL}$ with biofeedback therapy. Biofeedback therapy has been applied successfully in our clinic for many years and we have many studies in this field $(2,18,20)$. We found a significant improvement in DVISS, UF-EMG pattern and PVR as in other studies.

\section{Study Limitations}

In our study, we could measure the serotonin metabolite instead of serotonin. This situation can be regarded as the main limitation. We used urine specimens because it was difficult to get blood samples several times in children. Urine 5-HIAA results may be affected by the ingestion of tryptophan/serotonin-rich foods (avocados, bananas, kiwi fruit, melons, nuts, tomatoes, etc.) and certain medications and supplements (acetaminophen). It is important that these substances be avoided for 24 to 72 hours prior to urine sampling. We failed to comply with this rule.

\section{Conclusion}

Urine 5-HIAA has no place in the evaluation of the etiology and treatment success in childhood DV. New studies are needed to get more information about the role of neuromodulators in the etiology and treatment of DV.

\section{Ethics}

Ethics Committee Approval: This study was approved by the Gülhane Military Medical Academy Ethics Committee (approval number: 15, date: 3 April 2013).

Informed Consent: Consent form was filled out by all participants.

Peer-reviewed: Externally peer-reviewed.

\section{Authorship Contributions}

Surgical and Medical Practices: B.T., G.E., Concept: B.T., Y.K., Design: B.T., B.K., T.E., Data Collection or Processing: B.T., G.E., Analysis or Interpretation: H.C.I., Y.K., M.M.D., Literature Search: B.T., B.K., Writing: B.T.

Conflict of Interest: No conflict of interest was declared by the authors.

Financial Disclosure: The authors declared that this study received no financial support. 


\section{References}

1. Austin PF, Bauer SB, Bower W, Chase J, Franco I, Hoebeke P, Rittig S, Walle JV, von Gontard A, Wright A, Yang SS, Nevéus T. The standardization of terminology of lower urinary tract function in children and adolescents: Update report from the standardization committee of the International Children's Continence Society. Neurourol Urodyn 2016;35:471-481.

2. Ergin G, Kibar Y, Ebiloğlu T, Irkılata HC, Kopru B, Kaya E, Uyanık M, Tapan $\mathrm{S}$, Dayanc MM. The role of urinary nerve growth factor for the diagnosis and assessment of the biofeedback success in children with dysfunctional voiding. J Pediatr Urol 2016;12:118.

3. Van Batavia JP, Combs AJ, Fast AM, Glassberg KI. Use of non-invasive uroflowmetry with simultaneous electromyography to monitor patient response to treatment for lower urinary tract conditions. J Pediatr Urol 2014;10:532-537.

4. Sillén U, Brandström $P$, Jodal U, Holmdahl G, Sandin A, Sjöberg I, Hansson S. The Swedish reflux trial in children: v. Bladder dysfunction. J Urol 2010;184:298-304.

5. Dayanc MM, Kibar Y, Irkilata HC, Sancaktutar AA, Ebiloglu T, Gur A, Ergin G, Alp BF, Gok F. Effect of Voided Volume on Voiding Patterns and Reliability of Uroflowmetry-Electromyography Results in Children with Lower Urinary Tract Dysfunction. Low Urin Tract Symptoms 2017;9:46-51.

6. de Groat WC, Yoshimura N. Pharmacology of the lower urinary tract. Annu Rev Pharmacol Toxicol 2001;41:691-721.

7. Andersson KE. Treatment of the overactive bladder: possible central nervous system drug targets. Urology 2002;59(5 Suppl 1):18-24.

8. Boyer EW, Shannon M. The serotonin syndrome. N Engl J Med 2005;352:11121120.

9. van Dijk SC, de Herder WW, Kwekkeboom DJ, Zillikens MC, Feelders RA, van Schaik RH, van Driel $M$, van Leeuwen JP. 5-HIAA excretion is not associated with bone metabolism in carcinoid syndrome patients. Bone 2012;50:12601265.

10. Cheng $\mathrm{CL}$, de Groat WC. Role of 5-HT1A receptors in control of lower urinary tract function in anesthetized rats. Am J Physiol Renal Physiol 2010;298:771-778.
11. Dolber PC, Gu B, Zhang X, Fraser MO, Thor KB, Reiter JP. Activation of the external urethral sphincter central pattern generator by a $5-\mathrm{HT}(1 \mathrm{~A})$ receptor agonist in rats with chronic spinal cord injury. Am J Physiol Regul Integr Comp Physiol 2007;292:1699-1706.

12. Tellez MR, Mamikunian G, O'Dorisio TM, Vinik Al, Woltering EA. A single fasting plasma 5-HIAA value correlates with 24-hour urinary 5-HIAA values and other biomarkers in midgut neuroendocrine tumors (NETs). Pancreas 2013;42:405-410.

13. Jangjoo A, Varasteh AR, Mehrabi Bahar M, Tayyebi Meibodi $N$, Esmaili $\mathrm{H}$, Nazeri N, Aliakbarian M, Azizi SH. Is urinary 5-hydroxyindoleacetic acid helpful for early diagnosis of acute appendicitis? Am J Emerg Med 2012;30:540-544.

14. Leclair MD, Héloury Y. Non-neurogenic elimination disorders in children. J Pediatr Urol 2010;6:338-345.

15. Andersson KE, Wein AJ. Pharmacology of the lower urinary tract: basis for current and future treatments of urinary incontinence. Pharmacol Rev 2004;56:581-631.

16. Chen SC, Cheng CL, Fan WJ, Chen JJ, Lai CH, Peng CW. Effect of a 5-HT1A receptor agonist (8-OH-DPAT) on external urethral sphincter activity in a rat model of pudendal nerve injury. Am J Physiol Regul Integr Comp Physiol 2011;301:225-235.

17. Ellsworth PI, Merguerian PA, Copening ME. Sexual abuse: another causative factor in dysfunctional voiding. J Urol 1995;153:773-776.

18. Kibar Y, Demir E, Irkilata C, Ors O, Gok F, Dayanc M. Effect of biofeedback treatment on spinning top urethra in children with voiding dysfunction. Urology 2007;70:781-784.

19. Krzemiñska $K$, Maternik $M$, Drožyñska-Duklas $M$, Szczešniak $P$, Czarniak P, Gołèbiewski A, Zurowska A. High efficacy of biofeedback therapy for treatment of dysfunctional voiding in children. Cent European J Urol 2012;65:212-215.

20. Kibar Y, Ors O, Demir E, Kalman S, Sakallioglu O, Dayanc M. Results of biofeedback treatment on reflux resolution rates in children with dysfunctional voiding and vesicoureteral reflux. Urology 2007;70:563-566.

21. Shei Dei Yang S, Wang CC. Outpatient biofeedback relaxation of the pelvic floor in treating pediatric dysfunctional voiding: a short-course program is effective. Urol Int 2005;74:118-122. 